УдК 378.614.253.5

DOI 10.11603/2411-1597.2021.1.12076

\title{
ФОРМУВАННЯ ДОСЛІДНИЦЬКИХ УМІНЬ МАЙБУТНІХ МЕДИЧНИХ СЕСТЕР ЯК ПЕДАГОГІЧНА ПРОБЛЕМА
}

\author{
А. Р. Олійникова \\ Тернопільський національний медичний університет \\ імені І. Я. Горбачевського МОЗ Украӥни \\ ННІ медсестринства
}

\begin{abstract}
У статті обгрунтовано необхідність формування дослідницьких умінь майбутніх медичних сестер у процесі навчання в медичному коледжі. Актуалізовано значущість дослідницьких умінь в практичній охороні здоров’я і наявність відповідних їм організаційно-педагогічних умов у процесі професійної підготовки. Наведено дані емпіричного дослідження стану процесу формування розглянутих умінь в підготовці майбутніх медичних сестер у медичному коледжі.
\end{abstract}

\section{THE PROCESSE OF SCIENTIFIC SKILLS FORMATION FOR FUTURE NURSES AS A PEDAGOGICAL PROBLEM}

\author{
A. R. Oliinykova \\ I. Horbachevsky Ternopil National Medical University \\ Institute of Nursing
}

\begin{abstract}
The article analyses the need of scientific skills formation for future nurses in the process of studying at the medical college. The importance of scientific skills in practical health care and the availability of appropriate organizational and pedagogical skills in the process of professional training are updated. The data of empirical research of a condition of process of formation of the considered skills during preparation of future nurses in medical college are described.
\end{abstract}

Вступ. Вихід України на новий соціально-економічний рівень та поступова інтеграція в європейську спільноту суттєво підвищили вимоги до якості професійної підготовки фахівців. У галузі медичної освіти назріла потреба у висококваліфікованих, компетентних спеціалістах із медсестринства, здатних до самостійних дій, осмисленого аналізу і корекції своєї діяльності, самоосвіти та самовдосконалення. Реформування медсестринства зумовило впровадження триступеневої системи підготовки: молодший спеціаліст, бакалавр, магістр. Об'єктивною потребою й орієнтиром сьогодення $є$ створення підстав і умов для якісної підготовки майбутніх медичних працівників середньої ланки, готових надавати висококваліфіковану допомогу всім верствам населення, здійснювати свою професійну діяльність на рівні доказової медицини відповідно до концепції розвитку охорони здоров'я України. Досягнення поставленої мети неможливе без опанування дослідницьких вмінь й навичок.

(с) А. Р. Олійникова, 2021
Основна частина. Якість сучасної охорони здоров'я та стан здоров'я населення передусім залежать від професіоналізму медичних працівників, зокрема медичної сестри. Середній медичний персонал становить найчисленнішу категорію співробітників і розглядається як особливо значущий ресурс практичної охорони здоров'я. За сучасних умов значно зросли вимоги до майбутнього фахівця сестринської справи, спричинені низькими показниками здоров'я населення, запитом конкретних роботодавців та інших зацікавлених суб'єктів ринкових відносин (Т. Авраменко) [1].

Сучасний ринок праці розглядає медичних сестер як персонал, здатний проводити і організовувати дослідницьку роботу в лікувально-профілактичних установах на основі дослідницьких вмінь. Відтак, медичну сестру, згідно з очікуваннями роботодавців, характеризують як особистість, яка володіє ініціативою, самостійністю в прийнятті рішень. У зарубіжній моделі сестринської справи саме такий персонал

60 ISSN 2411-1597. МЕДСЕСТРИНСТВО. 2021. № 1 
працює в клініках, проводить наукові дослідження, що дозволяють систематизувати їхню роботу, обирати пріоритетні напрями, планувати і виконувати дії, які покращують стан пацієнта [6]. Однак підкреслимо, що випускники вітчизняної системи середньої медичної професійної освіти не відповідають висунутим вимогам і не володіють дослідницькими вміннями тією мірою, яка необхідна сучасній охороні здоров'я, роботодавцям, а головне, задоволенню потреб населення в профілактиці, лікуванні захворювань і реабілітації.

Сучасна медична сестра здійснює догляд за пацієнтом, проводить відновне лікування, навчає правильного способу життя при хронічних захворюваннях і травмах, що спричиняють втрату працездатності, елементів самодогляду і соціально адаптованої поведінки в суспільстві, проводить санітарно освітню роботу з населенням. Від того, наскільки таку роботу виконують професійно, грамотно і науково обґрунтовано, залежить загалом якість наданих послуг і здоров'я населення [5].

Особливості наукового підходу в сестринській справі, в основі яких є оптимізація якості допомоги населенню, охарактеризовані в дослідженні І. Хмеляр, яка зазначає, що нині медична сестра - не лише помічник лікаря, а самостійна професійна одиниця зі сформованим науково-практичним потенціалом [7]. Цілком очевидно, що охорона здоров'я потребує саме таких фахівців, а формування дослідницьких умінь майбутніх медичних сестер є актуальною проблемою професійної освіти.

Впровадження нових освітніх стандартів як відповідь на актуальну потребу в медичній сестрі нового типу зумовило необхідність розробки і реалізації інноваційної стратегії в підготовці медичних кадрів середньої ланки, де формуванню дослідницьких умінь студентів відводиться пріоритетна роль [4]. Припускаємо, що формування зазначених умінь має здійснюватися в процесі вивчення спеціальних дисциплін, представлених професійними модулями.

Тому формування дослідницьких умінь повинно спрямовуватися на навчання майбутніх медичних сестер у процесі професійної підготовки в медичному коледжі основ наукового дослідження, формуванню мотивів науково-дослідницької діяльності та дослідницьких вмінь. Вирішення таких важливих завдань дозволить не тільки підвищити якість підготовки медичних сестер, а й перетворює доктрину освітнього процесу в середній професійній освіті в практико зорієнтований контекст.
На думку М. Головань, дослідницькі вміння - це здатність студентів ефективно виконувати дії на основі використання знань, адекватних змісту кожного рівня системи освіти, вирішення поставленого завдання на основі наявних знань і умінь [3]. Таким чином, готовність до здійснення дослідницької діяльності на основі використання знань і практичних умінь 3 усвідомленням мети, умов і засобів діяльності $\epsilon$ професійно значущою якістю особистості майбутньої медичної сестри.

Дослідницькі вміння на основі їх різноаспектної практикоорієнтованої специфіки мають досить складну структуру і охоплюють кілька складників. Так, Т. Бабенко зазначає, що ефективність науково-дослідницької діяльності студентів залежить від таких компонентів: розвитку інфраструктури наукової та інноваційної діяльності освітньої установи; мотиваційного, орієнтованого, діяльнісного підходів; проблемних лекцій, практичних занять з елементами дослідження, методичних вимог і рекомендацій щодо організації різних форм науково-дослідницької діяльності [2].

Тому дослідницькі вміння майбутніх медичних сестер доцільно розглядати в єдності пізнавального інтересу; спеціальних знань, які стосуються специфіки, організації та проведення наукового та навчального дослідження, і предметних знань, що забезпечують понятійну базу вивчення і з'ясування певних процесів, фактів, явищ; сукупність спеціальних, інтелектуальних і предметних умінь. Відтак, дослідницькі вміння - це спрогнозовані способи дії, що забезпечують достовірність і об'єктивність дослідження, основаного на наукових знаннях, згідно з його логікою.

Одним з основних засобів формування дослідницькихумінь майбутніх медичних сестер є дослідницька діяльність, яку розглядають 3. Бакум та Т. Бабенко як цілеспрямовану організовану індивідуальну або групову роботу, спрямовану на вирішення професійних завдань і реалізовану в співпраці з викладачем в аудиторній і позааудиторній діяльності. Ії результативність залежить від системності та послідовності, науковопедагогічного забезпечення, оволодіння викладачем науково-дослідними вміннями, готовності викладача займатися науково-дослідницькою діяльністю зі студентами, тим самим підвищуючи мотивацію студентів у цій сфері [8].

Відтак, роль викладача в організації та проведенні науково-дослідницької діяльності в процесі навчання полягає в створенні необхідних умов для інтеграції 
науки і освіти в межах середньої професійної освіти, реалізації наукового потенціалу особистості студента медичного коледжу, підготовці конкурентоздатного випускника зі сформованими дослідницькими вміннями.

Проблема формування дослідницьких умінь майбутніх медичних сестер досить актуальна за умов сучасної професійної освіти. Для підтвердження актуальності означеної проблеми проведено дослідження, в якому взяли участь 120 майбутніх медичних сестер. Його мета - встановити, наскільки студенти володіють дослідницькими вміннями в обсязі, затребуваному населенням і роботодавцем, тобто закладами практичної охорони здоров'я. Дослідження охоплювало цикл запитань, що дозволяють визначити міру оволодіння дослідницькими вміннями, мотивами дослідницької діяльності, ставленням до неї. Ми мали намір з'ясувати також, чи вміють студенти вирішувати дослідницькі завдання. Всі ці питання необ-

\section{СПИСОК ЛІТЕРАТУРИ}

1. Авраменко Т. П. Кадрова політика у реформуванні сфери охорони здоров'я : аналітична доповідь / Т. П. Авраменко. - К. : НІСД, 2012. - 35 с.

2. Бабенко Т. П. Дослідницька діяльність студентів у контексті реформування медсестринської освіти / Т. П. Бабенко // Проблеми та перспективи розвитку науки на початку третього тисячоліття у країнах СНД : матеріали I Міжнародної науково-практичної інтернет-конференції (26-28 лютого 2012 р.). - Переяслав-Хмельницький, 2012. - С. 206-208.

3. Головань М. С. Модель формування дослідницької компетентності майбутніх фахівців у процесі професійної підготовки / М. С. Головань // Педагогічні науки: теорія, історія, інноваційні технології. - 2012. - № 5 (23). С. 196-205.

4. Макаренко В. І. Метод пошуково-дослідницьких проектів як засіб формування науково-дослідницьких хідні для надання інформації, пов'язаної з вивченням готовності студентів до дослідницької діяльності.

Висновки. На основі аналізу результатів анкетування встановлено наявність бажання і мотиву дослідницької діяльності студентів, проте теоретичний базис професійної підготовки майбутніх медичних сестер у коледжі нині не дозволяє ефективно формувати дослідницькі вміння згідно із запитами практичної охорони здоров'я. На практичних заняттях завдання з елементами дослідження мають обмежений характер, вибір методів і засобів навчання здійснюється переважно спонтанно, що свідчить про відсутність цілеспрямованої роботи з формування дослідницьких умінь. Ефективне формування досліджуваної якості стримується також відсутністю необхідних організаційно-педагогічних умов. Відтак, необхідно розвинути інфраструктуру наукової та інноваційної діяльності освітньої установи.

умінь студентів / В. І. Макаренко // Вища освіта України. Тематичний випуск «Педагогіка вищої школи: методологія, теорія, технології». - 2014. - № 3 (3). - С. 82-93.

5. Макаренко О. В. Методика формування дослідницької компетентності майбутніх лікарів у процесі вивчення природничих дисциплін : навч. посіб. / О. В. Макаренко. - Полтава : Шевченко Р. В., 2017. - 104 с.

6. Сестринские исследования за рубежом // Медицинская сестра. - 2018. - № 4. - С. 41-42.

7. Хмеляр І. Формування дослідницької компетентності студентів-лаборантів / І. Хмеляр // Нова педагогічна думка. - 2019. - № 3. - С. 152-156.

8. Bakum Z. Development of research abilities and skills of students studying in educational institutions of accreditation I-II level / Z. Bakum, T. Babenko // Social Educational Project of Improving Knowledge in Economic. - 2014. - Vol. 7. P. 6-9. 